\title{
Improvement in hand hygiene compliance. The impact of a regional strategy
}

\author{
P Rodriguez-Perez ${ }^{1 *}$, CC Mireia ${ }^{1}$, RR Cristina' ${ }^{1}$ PM Rosa ${ }^{1}$, JM Ana Belén ${ }^{1}$, NR Cristina ${ }^{2}$, PH Alberto² \\ From International Conference on Prevention \& Infection Control (ICPIC 2011) \\ Geneva, Switzerland. 29 June - 2 July 2011
}

\section{Introduction / objectives}

Health-care workers (HCWs) adherence to hand hygiene $(\mathrm{HH})$ guidelines is usually low. According to WHO recommendations, the key strategy components to improve the compliance is evaluation and feed-back.In this study we monitored HH compliance of HCWs by direct observation in Madrid and to asses the impact of an interventional strategy.

\section{Methods}

We observed 33 Madrid's Public Hospitals (more than 40.000 Health care workers) before and after the implementation of a regional intervention following WHO multimodal HH improvement strategy. It included different interventions but was specially focused in an online education tool with a play learning methodology. Our study involved a wide range of HWCs: dentists, physiotherapist, nurses, physicians and students. We performed a 6-week observation period, March-April 2010 and the same period in 2011.

\section{Results}

Around 10.000 opportunities for $\mathrm{HH}$ were observed in each period. Compliance in the first period was $30.9 \%$ (95\% C.I.:30-31.7). The second period is currently taking place, but an interim analysis reveals a $\mathrm{HH}$ compliance of a $47 \%(95 \%$ C.I.:44,92-49,38).

In the $1^{\text {st }}$ period the lowest compliance is achieved at the 2nd moment (14.6\%; before an aseptic task), followed by the 1 st moment (25.1\%; before patient contact). In the second period the use of alcohol based solutions have increased reaching a $77 \%$ of all $\mathrm{HH}$ performed. The technique has also improved.

${ }^{1}$ Medicina Preventiva, Hsopital General Universitario Gregorio Marańon, Spain

Full list of author information is available at the end of the article

\section{Conclusion}

The result of the regional strategy shows an important improvement in $\mathrm{HH}$ compliance.

We believe this improvement is having a impact in reducing health care associated infections. Further studies are needed to assure sustainability in time and impact in infection rates.

\section{Disclosure of interest}

None declared.

\section{Author details}

${ }^{1}$ Medicina Preventiva, Hsopital General Universitario Gregorio Marańon, Spain. ${ }^{2}$ Subdireccion General de Calidad, Consejería de Sanidad de la Comunidad de Madrid, Madrid, Spain.

Published: 29 June 2011

doi:10.1186/1753-6561-5-S6-067

Cite this article as: Rodriguez-Perez et al: Improvement in hand hygiene compliance. The impact of a regional strategy. BMC Proceedings 20115 (Suppl 6):O67.

Submit your next manuscript to BioMed Central and take full advantage of:

- Convenient online submission

- Thorough peer review

- No space constraints or color figure charges

- Immediate publication on acceptance

- Inclusion in PubMed, CAS, Scopus and Google Scholar

- Research which is freely available for redistribution

Submit your manuscript at www.biomedcentral.com/submit
( Biomed Central

\section{Biomed Central}

